\title{
Effect of simulated intragastric haemorrhage on gastric acid secretion, gastric motility, and serum gastrin
}

\author{
G M Fullarton, E J S Boyd, G P Crean, T E Hilditch, K E L McColl
}

\begin{abstract}
The majority of upper gastrointestinal bleeds stop spontaneously despite the low $\mathrm{pH}$ and proteolytic activity of gastric juice which inhibit coagulation and platelet aggregation. In order to investigate this paradox six healthy male volunteers received intragastric infusions of $160 \mathrm{ml}$ autologous venous blood or $160 \mathrm{ml}$ egg white acting as control in random order on separate days. Basal acid output was calculated before infusion, net acid secretion and gastric volume emptied were calculated after intragastric infusions. Serum gastrin concentrations were also measured before and after intragastric infusions and expressed as the integrated gastrin response. Basal acid output (mmol/h) was 4.7 (1.9) (mean (SEM)) before egg white infusion and $5.9(2.6)$ before venous blood infusion. After egg white infusion net acid secretion $(\mathrm{mmol} / 20 \mathrm{~min})$ increased to 5.6 (3.1) compared with $2.3(1.3)$ after venous blood infusion $(p<0.05)$. The gastric volume emptied $(\mathrm{ml} / 20 \mathrm{~min})$ was less after venous blood infusion at 105 (28) compared with 321 (66) after egg white infusion $(\mathbf{p}<0.03)$. Integrated gastrin response was similar after venous blood and egg white infusion. When compared with an equivalent protein meal intragastric blood stimulates less acid secretion and delays gastric emptying. This effect may facilitate haemostasis after gastric bleeding.
\end{abstract}

Despite the multiplicity of aggressive factors present in the upper gastrointestinal tract most gastroduodenal bleeds stop spontaneously. This is surprising in view of the high acidity, proteolytic activity, vascularity and motile nature of the upper gastrointestinal tract, all factors which should act to inhibit haemostasis and promote haemorrhage.

Initial experimental studies in normal volunteers have shown that simulated duodenal haemorrhage inhibits acid and pepsin secretion and delays gastric emptying, responses which may facilitate haemostasis in the adverse environment of the upper gastrointestinal tract. ${ }^{\prime}$ It is common in upper gastrointestinal bleeding, however, for blood to be found in the stomach either indirectly from an oesophageal or duodenal source, or directly from a gastric lesion. Intragastric blood constitutes a concentrated protein meal which would be expected to stimulate gastric secretion by both neural and hormonal mechanisms ${ }^{2-1}$ and possibly overcome any protective responses induced by duodenal blood. It is important therefore to establish the effects of intragastric blood on gastric secretion and motility to determine whether similar protective responses occur. The aim of this study was to examine the effects of simulated intragastric haemorrhage on gastric acid secretion, gastric emptying and serum gastrin concentrations.

\section{Methods}

GASTRIC SECRETION AND MOTILITY STUDY

Studies were performed in six healthy male volunteers (median age 29 years, range 28-36).

After an overnight $(12 \mathrm{~h})$ fast a size $10 \mathrm{FG}$ vented nasogastric tube (Andersen Inc, New York) was passed perorally into the stomach and its satisfactory position for aspiration confirmed by a water recovery test. ${ }^{5}$ At time -30 minutes continuous nasogastric suction was started and two 15 minute basal gastric collections were taken, the volume of each noted and a $5 \mathrm{ml}$ aliquot retained for analysis. At time -10 minutes each volunteer was blindfolded and 160 $\mathrm{ml}$ venous blood removed in $4 \times 40 \mathrm{ml}$ heparinised syringes ( $250 \mathrm{U}$ sodium heparin $/ 40 \mathrm{ml}$ syringe) at two minute intervals. The intragastric blood was heparinised as initial studies with unheparinised blood clotted which precluded adequate mixing and aspiration of gastric contents. Volunteers were then randomised to receive intragastrically either $160 \mathrm{ml}$ of autologous heparinised venous blood or $160 \mathrm{ml}$ egg white acting as a control having similar nutrient content, $\mathrm{pH}$ and osmolality to blood (Table I). At time 0 minutes blood or egg white was introduced into the stomach as $4 \times 40 \mathrm{ml}$ aliquots at 1 minute intervals, each aliquot having $5 \mathrm{ml}$ ${ }^{1+} \mathrm{C}$-polyethylene glycol (PEG) (Amersham International) added as a non-absorbable marker. A $5 \mathrm{ml}$ aliquot of this test meal mixture was retained for ${ }^{14} \mathrm{C}-\mathrm{PEG}$ assay. The total dose of ${ }^{14} \mathrm{C}$-PEG infused into the stomach was equivalent to $0.9 \mathrm{MBq}$. Immediately after the last aliquot of blood or egg white was given the intragastric contents were mixed and a $10 \mathrm{ml}$ aliquot retained for analysis. The gastric contents continued to be mixed at regular intervals and a further $10 \mathrm{ml}$ aliquot was removed at 10 minutes for analysis. At 20 minutes the stomach was emptied completely, the volume noted, and

\begin{tabular}{|c|c|c|c|c|c|}
\hline & $\begin{array}{l}\text { Protein } \\
(\mathrm{g} / 100 \mathrm{ml})\end{array}$ & $\underset{(\mathrm{g} / 100 \mathrm{ml})}{\mathrm{CHO}}$ & $\begin{array}{l}F a t \\
(\mathrm{~g} / 100 \mathrm{ml})\end{array}$ & $\begin{array}{l}\text { Osmolality } \\
\text { (mosmol/kg) }\end{array}$ & $p H$ \\
\hline $\begin{array}{l}\text { Egg-white } \\
\text { Blood }\end{array}$ & $\begin{array}{l}10 \cdot 8 \\
22\end{array}$ & $\begin{array}{l}0.4 \\
0.6\end{array}$ & $\begin{array}{l}0.05 \\
0.6\end{array}$ & $\begin{array}{l}230 \\
280\end{array}$ & $\begin{array}{l}7 \cdot 8 \\
7 \cdot 5\end{array}$ \\
\hline
\end{tabular}

${ }^{\star}$ Based on Romanoff ${ }^{\natural}$ and Lentner ${ }^{`} ; \mathrm{CHO}=$ carbohydrate.

\author{
Bioengineering, West \\ Graham Street, Glasgow \\ T E Hilditch \\ Correspondence to \\ Mr GM Fullarton, FRCS, \\ Department of Surgery, \\ G11 6NT. \\ Accepted for publication \\ 10 July 1989 \\ of Surgery and Medicine \\ Western Infirm \\ Southern General \\ G M Fullarton \\ E J S Boyd \\ G P Crean
K E L McColl

Department of Clinical
Physics and
Bioengineering, West
Graham Street, Glasgow
T E Hilditch
Correspondence to:
Mr G M Fullarton, FRCS,
Department of Surgery,
Western Infirmary, Glasgow
G11 6NT.
Accepted for publication
10 July 1989


TABLE II Gastric secretory parameters after intragastric blood and egg white in six volunteers

\begin{tabular}{|c|c|c|c|c|}
\hline \multirow{2}{*}{$\begin{array}{l}\text { Subject } \\
\text { No }\end{array}$} & \multicolumn{2}{|c|}{$\begin{array}{l}\text { Acid concentration } \\
(\text { mmolll })\end{array}$} & \multicolumn{2}{|c|}{$\begin{array}{l}\text { Net } H^{\prime} \text { secretion } \\
(\mathrm{mmol} / 20 \mathrm{~min})\end{array}$} \\
\hline & Egg white & Blood & Egg white & Blood \\
\hline $\begin{array}{l}1 \\
2 \\
3 \\
4 \\
5 \\
6\end{array}$ & $\begin{array}{r}20 \cdot 8 \\
66 \cdot 3 \\
59 \cdot 6 \\
50 \cdot 7 \\
42 \cdot 2 \\
2 \cdot 8\end{array}$ & $\begin{array}{r}16 \cdot 1 \\
4.9 \\
48 \cdot 5 \\
2 \cdot 4 \\
23.9 \\
3.6\end{array}$ & $\begin{array}{r}2 \cdot 0 \\
5 \cdot 0 \\
20 \cdot 9 \\
1 \cdot 2 \\
4 \cdot 2 \\
0.2\end{array}$ & $\begin{array}{l}0.6 \\
0.5 \\
8.3 \\
0.3 \\
3.8 \\
0.3\end{array}$ \\
\hline $\begin{array}{l}\text { Mean } \\
\text { SEM }\end{array}$ & $\begin{array}{c}40.4 \\
9.9 \\
p<0.05\end{array}$ & $\begin{array}{r}16 \cdot 6 \\
7 \cdot 2\end{array}$ & $\begin{array}{c}5.6 \\
3.1 \\
p<0.05\end{array}$ & $\begin{array}{l}2 \cdot 3 \\
1 \cdot 3\end{array}$ \\
\hline
\end{tabular}

Acid concentration $=$ concentration of acid $(\mathrm{mmol} / \mathrm{l})$ aspirated from the stomach 20 minutes after intragastric infusions. Net $\mathrm{H}$ secretion $=$ calculated acid secretion $(\mathrm{mmol} / 20 \mathrm{~min})$ after intragastric infusions.

a $10 \mathrm{ml}$ aliquot retained for analysis. After this, the stomach was then lavaged with $100 \mathrm{ml}$ distilled water, the residual volume recorded (wash volume) and a $10 \mathrm{ml}$ sample retained for analysis. Each subject underwent an identical study with the alternative intragastric infusate at least one week later. On each occasion the same volume of blood was removed. On egg white infusion days this was discarded.

\section{GASTRIN STUDIES}

Serial blood samples were taken before and after intragastric infusions to investigate changes in gastrin secretion. Three $10 \mathrm{ml}$ samples of venous blood were removed at 15 minute intervals during the basal collection period and added to heparinised tubes at times $-30,-15$, and 0 minutes. After intragastric infusions further venous blood samples were taken at 15 minute intervals until time 60 minutes with the final sample taken 90 minutes after the start of the infusions. All heparinised venous blood samples were immediately centrifuged, the plasma removed and stored at $-20^{\circ} \mathrm{C}$ for later assay.

\section{ANALYSIS}

\section{Gastric secretion}

Gastric juice was analysed for: (1) hydrogen ion concentration by automatic titration to $\mathrm{pH} 7 \cdot 0$ with $100 \mathrm{mmol} / \mathrm{l}$ sodium hydroxide using an Autotitrator (Radiometer, ETS 822, Copenhagen). (2) ${ }^{14} \mathrm{C}-\mathrm{PEG}$ radioassay was measured

TABLE III Gastric secretion and volume changes after intragastric blood and egg white in six volunteers

\begin{tabular}{|c|c|c|c|c|c|c|}
\hline \multirow{2}{*}{$\begin{array}{l}\text { Subject } \\
\text { No }\end{array}$} & \multicolumn{2}{|l|}{$\begin{array}{l}V c \\
(m l)\end{array}$} & \multicolumn{2}{|c|}{$\begin{array}{l}V p \\
(\mathrm{ml} / 20 \mathrm{~min})\end{array}$} & \multicolumn{2}{|c|}{$\begin{array}{l}V s \\
(\mathrm{ml} / 20 \mathrm{~min})\end{array}$} \\
\hline & Egg white & Blood & Egg white & Blood & Egg white & Blood \\
\hline $\begin{array}{l}1 \\
2 \\
3 \\
4 \\
5 \\
6\end{array}$ & $\begin{array}{l}94 \cdot 2 \\
35 \cdot 0 \\
60 \cdot 9 \\
23 \cdot 3 \\
61 \cdot 4 \\
69 \cdot 4\end{array}$ & $\begin{array}{r}37 \cdot 3 \\
107 \cdot 5 \\
119 \cdot 4 \\
124 \cdot 8 \\
142 \cdot 6 \\
83.0\end{array}$ & $\begin{array}{l}334 \cdot 0 \\
250 \cdot 2 \\
637 \cdot 0 \\
265 \cdot 9 \\
255 \cdot 2 \\
182 \cdot 7\end{array}$ & $\begin{array}{r}204.9 \\
94 \cdot 2 \\
148.6 \\
2.6 \\
63.9 \\
115.5\end{array}$ & $\begin{array}{r}248 \cdot 3 \\
105 \cdot 2 \\
518 \cdot 0 \\
109 \cdot 2 \\
136 \cdot 6 \\
72 \cdot 0\end{array}$ & $\begin{array}{l}62 \cdot 2 \\
21 \cdot 6 \\
87 \cdot 9 \\
52 \cdot 6 \\
26 \cdot 5 \\
18 \cdot 5\end{array}$ \\
\hline $\begin{array}{l}\text { Mean } \\
\text { SEM }\end{array}$ & $\begin{array}{l}57.4 \\
10.3 \\
p=0.07\end{array}$ & $\begin{array}{r}102 \cdot 4 \\
15 \cdot 3\end{array}$ & $\begin{array}{c}320.8 \\
66.2 \\
p<0.03\end{array}$ & $\begin{array}{r}105 \cdot 0 \\
28.5\end{array}$ & $\begin{array}{c}198.2 \\
68.6 \\
p<0.03\end{array}$ & $\begin{array}{l}36 \cdot 1 \\
13 \cdot 3\end{array}$ \\
\hline
\end{tabular}

$\mathrm{V} c=$ corrected volume recovered from stomach; $\mathrm{Vp}=$ volume discharged through pylorus in 20 minutes; Vs=volume secreted in 20 minutes. by liquid scintillation counting (Packard TriCarb 300, Canberra Packard, Berks). Aliquots $(0.2 \mathrm{ml})$ of each gastric sample were initially added to a solubiliser solution Soluene 350 (Canberra Packard) and iso-propyl alcohol in a 1:2 volume ratio. After overnight incubation to allow complete solubilisation, $0.5 \mathrm{ml}$ hydrogen peroxide solution was added and samples incubated at $40^{\circ}$ Centigrade for a further 30 minutes. At this stage, $10 \mathrm{ml}$ Hionic Fluor Scintillator (Canberra Packard) was added and counted for 10 minutes under ${ }^{1+} \mathrm{C}$ conditions with an inbuilt quench correction.

\section{GASTRIN}

The gastrin assay was performed by radioimmunoassay using antibody $\mathrm{R} 98$ which has a lower limit of detection of $2 \cdot 4 \mathrm{pmol} / 1 .^{8}$ The gastrin estimations were all performed in a single batch.

\section{CALCULATIONS}

\section{Gastric secretion and motility}

(a) Basal acid output ( $\mathrm{mmol} / \mathrm{h}$ ) was calculated by summing the outputs during the two 15 minute basal collection periods and multiplying by two. (b) To calculate net gastric secretion and transpyloric loss of gastric contents the method of Hunt ${ }^{9}$ was used (see appendix).

\section{GASTRIN}

Fasting gastrin values were expressed as the mean of the three preinfusion samples at -30 , -15 , and 0 minutes. The integrated response to intragastric blood and egg white was calculated for each individual by estimating the area under the plasma gastrin/time curve using the trapezoidal method. ${ }^{10}$

STATISTICAL ANALYSIS

Results are given as mean standard error of the mean (SEM). Statistical analysis was performed using the paired Wilcoxon's signed-rank test (two sided). Results were considered significant when $\mathrm{p} \leqslant 0 \cdot 05$.

Written, fully informed consent was obtained in each case and the study was approved by the local hospital Ethical Committee.

\section{Results}

\section{GASTRIC SECRETION}

\section{(a) Basal secretion}

The mean basal acid output (mmol/h) before infusions was $5.9(2 \cdot 6)$ on the blood infusion day and $4.7(1.9)$ on the egg white infusion day $(p=$ NS).

\section{(b) Acid concentration}

The concentration of acid ( $\mathrm{mmol} / \mathrm{l})$ aspirated from the stomach after 20 minutes was $40 \cdot 4(9 \cdot 9)$ after egg white infusion and 16.6 (7.2) after blood infusion $(\mathrm{p}<0 \cdot 05)$ (Table II). 
Figure: Plasma gastrin concentrations before and after intragastric infusion of $160 \mathrm{ml}$ blood and egg white in six healthy volunteers. Results are given as mean (SEM).

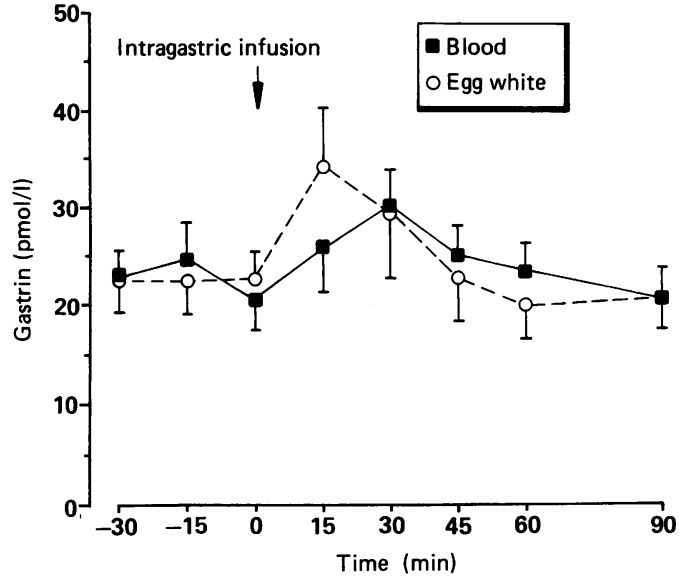

(c) Volume secreted (V.s)

There was an increase in secretion rates $(\mathrm{ml} / 20$ min) after intragastric egg white infusion being $198 \cdot 2$ (68.6) compared with $36 \cdot 1$ (13.3) after intragastric blood infusion $(p<0.03)$ (Table III).

\section{(d) Net acid secretion}

There was a positive net flux of acid (net secretion of acid) in all six volunteers after both egg white and blood infusion. Net acid secretion $(\mathrm{mmol} / 20 \mathrm{~min})$, however, was less after intragastric blood infusion being $2 \cdot 3(1 \cdot 3)$ compared with $5.6(3 \cdot 1)$ after egg white infusion $(\mathrm{p}<0.05)$ (Table II).

\section{GASTRIC EMPTYING}

(a) Corrected residual volume (Vc)

The corrected residual gastric volume $(\mathrm{ml})$ at 20 minutes was $57 \cdot 4(10 \cdot 3)$ after intragastric egg white infusion and $102.4(15.3)$ after blood infusion $(p=0 \cdot 07)$ (Table III).

\section{(b) Volume emptied through the pylorus $(V p)$}

The volume $(\mathrm{ml} / 20 \mathrm{~min})$ emptied from the stomach was less after intragastric blood infusion being $105(28.5)$ compared with $320.8(66.2)$ after intragastric egg white infusion $(\mathrm{p}<0.03)$ (Table III).

CORRELATION BETWEEN RATE OF EMPTY ING AND RATE OF SECRETION

There was a significant positive correlation between the volume emptied through the pylorus $(\mathrm{Vp})$ and net acid secretion over 20 minutes after intragastric egg white infusion $(\mathrm{r}=0.94 ; \mathrm{p}<0.01)$ but not after blood infusion $(\mathrm{r}=0.21 ; \mathrm{p}>0 \cdot 1)$. There was also a significant positive correlation between the $\mathrm{Vp}$ and the volume secreted into the stomach over 20 minutes (Vs) after both intragastric egg white infusion $(r=0.99 ; p<0.001)$ and blood infusion $(\mathrm{r}=0.86 ; \mathrm{p}<0.03)$.

\section{GASTRIN}

Fasting serum gastrin concentrations (pmol/l) were $22 \cdot 8(3 \cdot 8)$ before intragastric blood infusion and $22.6(3 \cdot 7)$ before egg white infusion $(p>0 \cdot 1)$ (Figure). Gastrin concentrations (pmol/l) increased above fasting values after both intragastric egg white and blood infusion (Figure). The integrated gastrin response ( $\mathrm{pmol} / \mathrm{l} / \mathrm{min}$ ), was similar after intragastric blood infusion being 1839 (274) compared with 1906 (404) after egg white infusion.

\section{Discussion}

This study has shown that intragastric blood infusion significantly stimulates less acid secretion and delays gastric emptying compared with an equivalent protein meal. In contrast there were no differences in the integrated serum gastrin response after either intragastric blood or egg white infusion.

These results suggest that intragastric blood does not act as a protein meal and is not therefore a potent stimulus to acid secretion. In the context of an upper gastrointestinal bleed these responses may be beneficial in promoting haemostasis.

Intragastric protein normally acts as a potent stimulus to acid secretion ${ }^{2112}$ and serum gastrin. ${ }^{413}$ This stimulatory action of intragastric protein is initiated by particular amino acids and/ or peptone fragments ${ }^{1214}$ and is gastrin mediated. ${ }^{15}$ Egg white being essentially an albumin solution has approximately similar amino acid content to blood. ${ }^{61617}$ It is therefore particularly surprising to show significantly less acid secretion after infusion of intragastric blood compared with egg white. In this study intragastric blood induced a median acid secretion of $0.5 \mathrm{mmol} / 20$ minutes which was $70 \%$ less than that induced by egg white infusion (median $3 \cdot 1$ $\mathrm{mmol} / 20 \mathrm{~min}$ ).

With intragastric egg white infusion there was as expected a significant positive correlation between the volume emptied into the duodenum and the rate of acid secretion. This correlation did not exist, however, when blood was introduced into the stomach suggesting that intragastric blood interferes with this normal physiological response.

The differences in secretion rates after intragastric egg white and blood cannot be explained on the basis of differences in gastrin release. This would suggest inhibitory mediation of parietal cell function either directly or indirectly by inhibition of gastrin induced acid secretion. Somatostatin is a candidate inhibitory mediator which suppresses both gastrin stimulated ${ }^{18}$ and food stimulated ${ }^{19}$ acid secretion possibly by a direct action on the parietal cells. ${ }^{20}$ Other possible inhibitory mediators include the hormones of the secretin group (secretin, glucagon, gastric inhibitory polypeptide) which also inhibit the action of gastrin on parietal cells possibly through somatostatin release. ${ }^{21-23}$

The inhibition of gastric emptying noted in this study after intragastric blood infusion compared with egg white infusion must be independent of the factors known to influence gastric emptying which include the $\mathrm{pH},{ }^{24}$ osmolality, ${ }^{25}$ nutrient content, ${ }^{26}$ and volume ${ }^{27}$ of the meal as these parameters were similar in each of the study groups. Recent evidence suggests that gastric emptying of a liquid meal may involve alteration of antro pyloroduodenal motor activity 
possibly by stimulation of duodenal receptors..$^{28}$ Such duodenal receptors are not simply $\mathrm{pH}$ or osmolarity sensors but may be sensitive to other intraluminal stimuli such as glucose. ${ }^{29}$ It is interesting to speculate that the duodenal receptors may also respond to intraluminal blood or its products to slow gastric emptying possibly mediated by inhibitory gastrointestinal hormones. In the context of upper gastrointestinal bleeding reduced gastric motility is likely to be beneficial by preventing clot dislodgement, decreasing duodenal acid delivery and gastric blood flow requirements.

In conclusion, this study has shown that intragastric blood infusion induces weak gastric acid secretion and inhibits gastric emptying without alteration of integrated gastrin response compared with an equivalent egg white infusion. This suggests that contrary to expectations intragastric blood does not behave as a protein meal, an effect which may represent an additional protective mechanism in upper gastrointestinal haemorrhage.

\section{Appendix}

CALCULATIONS OF NET GASTRIC SECRETION AND TRANSPYLORIC LOSSES

The following symbols have been used:

$\mathrm{V} 1=$ volume of test meal instilled

$\mathrm{V} 2=$ volume aspirated after 20 minutes

$\mathrm{V} 3=$ wash volume

$\mathrm{Vp}=$ volume discharged through the pylorus in 20 minutes

$\mathrm{Vs}=$ volume secreted in 20 minutes (this represents the resultant of the volume of gastric secretions plus the volume of contaminant secretions that is, saliva, duodenogastric reflux, minus the volume of water absorbed from the stomach)

PEGl $=$ PEG concentration in test meal

$\mathrm{PEG} 2=\mathrm{PEG}$ concentration in aspirate at 10 minutes

PEG3 = PEG concentration in aspirate at 20 minutes

PEG4 = PEG concentration in wash

$\mathrm{Cl}=\mathrm{H}^{+}$concentration in test meal

$\mathrm{C} 2=\mathrm{H}^{+}$concentration in aspirate at $\mathbf{1 0}$ minutes

C3 $=\mathrm{H}^{+}$concentration at 20 minutes

The following equations were then used to calculate net fluxes and volume changes:

(1) Residual Volume (Vr) = V3 (PEG4/PEG3)

(2) Corrected volume recovered from stomach

$(\mathrm{Vc})=\mathrm{V} 2+\mathrm{Vr}$

(3) $\mathrm{Vp}=(\mathrm{V} 1 \mathrm{PEG} 1-\mathrm{Vc}$ PEG3)/PEG2

(4) $\mathrm{Vs}=\mathrm{Vc}+\mathrm{Vp}-\mathrm{Vl}$

(5) Net secretion of $\mathrm{H}^{+}=$(Vc. $\mathrm{C} 3+\mathrm{Vp} . \mathrm{C} 2-$ V1. C1)
Our thanks to Professor K Buchanan, Department of Medicine, Queens University, Belfast for performing the gastrin assays and to Mrs D Park for typing the manuscript.

1 Fullarton GM, Boyd EJS, Crean GP, Buchanan K, McColl KEL. Inhibition of gastric secretion and motility by simulated upper gastrointestinal haemorrhage: a response to facilitate haemostasis? Gut 1989; 30: 156-60.

2 Beaumont W. Experiments and observations on the gastric juice and the physiology of digestion. Plattsburgh: F P Allen, 1833 125-30.

3 Woodward ER, Lyon ES, Landor J, et al. The physiology of the gastric antrum: experimental studies on isolated antrum pouches in dogs. Gastroenterology 1954; 27 : 766-78.

4 Grossman MI. Neural and hormonal stimulation of gastric secretion of acid. In: Code CF, ed. Alimentary canal. Washington DC: American Physiological Society, 1967: 835-63. (Heidel W, ed. Handbook of physiology, section 6: $835-63$.
vol II).

5 Hassan MA, Hobsley M. Positioning of subject and of nasogastric tube during a gastric secretion study. $\mathrm{Br} \mathrm{Med} \mathcal{F}$ 1970 ; i: 458-60

6 Romanoff AL, Romanoff AJ, eds. The avian egg. New York: John Wiley and Sons, 1949; $311-490$

7 Lentner C, ed. Geigy Scientific Tables. Volume 1. Units of measurement, body fluids, composition of body, nutrition. Basle: Ciba-Geigy, 1981: 254.

8 Ardill JES. The measurement of gastrin by radioimmunoassay [PhD Thesis]. Queen's University of Belfast, 1973.

9 Hunt JN. The secretory pattern of the stomach in man f Physiol (Lond) 1951; 113: 169-84

10 Yeh KC, Kwan K. A comparison of numerical integrating algorithms by trapezoidal, Lagrange, and spline approximaalgorithms by trapezoidal, Lagrange, and spline
tions. $\mathcal{F}$ Pharmacokinet Biopharm 1978; 6: 79-86.

11 Saint-Hilaire S, Lavers J, Kennedy J, Code CF. Gastric acid secretory value of different foods. Gastroenterology 1960; 39: $1-11$.

12 Elwin CE. Gastric acid responses to antral application of some amino acids, peptides and isolated fractions of a protein hydrolysate. Scand f Gastroenterol 1974; 9: 239-47.

13 Ganguli PC. The effect of protein, carbohydrate or fat on plasma gastrin concentration in human subjects. [Abstract] Gut 1970; 11: 1061 .

14 Ivy AC, Javois AJ. Contributions to the physiology of gastric secretion. Am F Physiol 1925; 71: 591-603.

15 Walsh JH, Yalow RS, Berson SA. The effect of atropine on plasma gastrin response to feeding. Gastroenterology 1971; 60: $16-21$.

16 Bragg PD, Hough L. An investigation of the egg-white mucoproteins, ovomucoid and ovalbumin. Biochem f 1961; 78: 1123 .

17 Parkinson TL. The chemical composition of eggs. $\mathcal{F}$ Sci Food Agric 1966; 17: 101-11.

18 Raptis S, Dollinger HC, Von Berger L, et al. Effects of somatostatin on gastric secretion and gastrin release in man somatostatin on gastric secre
Digestion 1975; 13: 15-26.

19 Konturek SJ, Tasler J, Cieszkowski M, Coy DH, Schally AV. Effect of growth hormone release-inhibiting hormone on gastric secretion, mucosal blood flow and serum gastrin. Gastroenterology 1976; 70: 737-46.

20 Bloom SR, Mortimer CH, Thorner MD, et al. Inhibition of gastrin and gastric acid secretion by growth hormone release-inhibiting hormone. Lancet 1974; ii: 1106-9.

21 Chiba T, Taminato T, Kadowaki S, et al. Effects of glucagon, secretin, and vasoactive intestinal polypeptide on gastric somatostatin and gastrin release from isolated perfused rat stomach. Gastroenterology 1980; 79: 67-71.

22 McIntosh CHS, Pederson RA, Koop H, Brown JC. Gastric inhibitory polypeptide stimulated secretion of somatostatinlike immunoreactivity from the stomach: inhibition by like immunoreactivity from the stomach: inhibition by acetylcholine or vaga

23 Wolfe MM, Reel GM, McGuigan JE. Inhibition of gastrin release by secretin is mediated by somatostatin in cultured rat antral mucosa. F Clin Invest 1983; 72: 1586-93.

24 Hunt JN, Knox MT. The regulation of gastric emptying of meals containing citric acid and salts of citric acid. $\mathcal{F}$ Physio 1962; 163: 34-45.

25 Hunt JN. The duodenal regulation of gastric emptying Gastroenterology 1963; 45: 149-56.

26 White CM, Poxon V, Alexander Williams J. Effects of nutrient liquids on human gastroduodenal motor activity. Gut 1983 24: 1109-16.

27 Hunt JN, MacDonald I. The influence of volume on gastric emptying. F Physiol (Lond) 1954; 126: 459-74.

28 Houghton LA, Read NW, Heddle R, et al. Motor activity of the gastric antrum, pylorus and duodenum under fasted conditions and after a liquid meal. Gastroenterology 1988; 94: condition $1276-84$.

29 Mei N. Vagal glucoreceptors in the small intestine of the cat f Physiol 1978; 282; 485-506. 